\title{
Effect of Predisposing Factors (Education, Economic Level, Knowledge and Attitude) on Defecation Behavior in Bener Meriah Regency
}

\author{
Syarifah $^{1}$, Ida Yustina ${ }^{2}$, Namora Lumongga Lubis $^{2}$ \\ ${ }^{1}$ Master Student in Universitas Sumatera Utara, Medan, Indonesia \\ ${ }^{2}$ Lecturer in Universitas Sumatera Utara, Medan, Indonesia \\ Email: syarifah_ifah40@yahoo.com
}

\begin{abstract}
:
This study discusses about factors affecting predisposing factors (education, economic level, knowledge and attitude) on defecation behavior in Bener Meriah Regency.

This research was conducted in Bener Meriah Regency which consists of 10 districts with the following considerations: (1) Indiscriminate defecation (BABS) behavior of 36.7 percent, this is far from the minimum service standard target (SPM) of 100 percent the community does not defecate carelessly; (2) Achievement of clean and healthy living behavior is only 24.7 percent, (3) Achievement of total community-based sanitation is only 3.0 percent of the target of 100 percent; (4) The research location is easy to reach by researchers. The result shows that the education of the head of the family has an influence on the behavior of open defecation. The economic level of the head of the family influences the behavior of open defecation. The attitude of the head of the family has an influence on the behavior of open defecation
\end{abstract}

Keywords:

predisposing; defecation behavior; Bener Meriah Regency

\section{Introduction}

Unhygienic behavior is still a problem in the community, not only found in rural areas, but in urban areas are still often found residents who defecate carelessly. Open defecation or open defecation is an unhealthy behavior, which is the behavior or habit of defecating in the open environment, for example in gardens / fields, rice fields, streams, ponds, beaches or in the yard of the house, by letting the occurrence of pollution in the environment, soil, air and water, so that it can cause disease (Sukma et al, 2018).

The importance of creating a healthy environment is sometimes not considered a crucial thing or priority because it is judged that it cannot immediately be a leverage for a development, even though the impact of losses caused by a bad environment is very large from the emergence of various health problems to the impact on economic losses (Prianto et al 2015).

According to the United States Agency for International Development (USAID) (2016) high morbidity and mortality due to open defecation is now a global problem, especially in developing countries that have high population growth rates. Transmission of diseases related to the use of water sources and sanitation related to open defecation cannot be completed, ie around 2.5 billion more people on earth do not have a toilet / toilet according to health standards.

Based on data from the World Health Organization (WHO) cited by Novitry and Agustin (2017) estimates that around 1.1 billion (17\%) of the population on this earth still defecate in any place, and about 81 percent who dispose of sewage is not in place there in 10 
countries in the world. Indonesia is the second largest country with around 12.9 percent of the community still defecating anywhere, while India is ranked first at 58 percent. This has resulted in more than 3,400,000 people dying each year, due to diseases originating from poor water and sanitation quality, one of which is diarrhea causing 1,400,000 deaths each year.

Getting used to defecate in a healthy manner can be a breaker in the path of contamination with human waste as a source of ongoing disease, namely by preparing and maintaining defecation facilities according to the health standards of the Ministry of Health (2014)

Seeing the magnitude of the impact of disease transmission caused by BABS, the Sustainable Development Goals (SDGs) program, especially the environmental part, sets targets in 2030, one of which is that all communities can utilize clean water and basic sanitation. This will be a tough task for Indonesia in achieving the 2015-2019 National Medium-Term Development Plan (RJPMN) target which stipulates that one of them is 100 percent of the community does not defecate carelessly. But until 2015 there were 62 million $(53 \%)$ of the population in rural areas did not have access to proper sanitation, 34 million of whom were practicing open defecation, meaning that 40 percent needed more acceleration to reach the 100 percent target, Indonesia stopped open defecation ( Ministry of Health, 2016)

To support changes in the health sector, especially disease control and environmental health, promotive and preventive efforts are carried out through community empowerment, which is expected to be able to implement Clean and Healthy Behavior (PHBS) in the household through the active role of family members to increase awareness, willingness to maintain health by not practicing open defecation (Umaroh et al, 2015).

\subsection{Open Defecation}

\section{Review of Literature}

Open defecation is an example of unhealthy behavior, which is a habit of defecating in the open environment such as in gardens / fields, fields, streams, ponds, beaches or in the yard of the house by allowing environmental pollution, land, air and water, which can cause disease (Minister of Health, 2014).

Open defecation is a system or way for humans to dispose of unclean / fecal matter, either solid or semi-solid produced by the body, and discharged in an open environment such as ponds, streams, fields and others, so that it can become a place to grow and develop seeds diseases that can be transmitted to the human body (Anwar et al., 2017). And it is strengthened by the statement of Putra and Selviana (2017), that defecation behavior in any place is a habit that is carried out by someone, because it follows the habits of the people around them, especially family.

Cintya (2017) interprets defecation behavior is a person's habit to defecate in fields, riverbanks, beaches and other places so that it pollutes the environment which can endanger human health. According to Chandra in Paramita and Sulistyorini, (2016) defines the behavior of defecation in any place is a human act that does not manage stool properly, thus polluting the environment which can have a negative impact on health.

\subsection{Community Based Total Sanitation}

Community Based Total Sanitation is an approach to rural sanitation development, which was first carried out on several communities in Bangladesh, then adopted by one of the 
Indian states, namely the Maharasta Province to include a comprehensive Community Based Total Sanitation program named the Total Sanitation Campaign (TSC). Even followed by several other countries such as Mongolia, Nepal, Cambodia and Aprika, currently also implementing Community Based Total Sanitation programs within certain targets (Ministry of Health of the Republic of Indonesia, 2014).

Community-based total sanitation is a way of approaching program strategies to change sanitation hygiene behavior through community empowerment with the triggering method. Total sanitation is a condition of the community not doing open defecation or Open Defecation Free (ODF). The principle of the activities of Community Based Total Sanitation implementation is to eliminate subsidies for basic sanitation facilities with the aim of exploring the potential of the community in building sanitation facilities privately by develop social solidarity in the community (Dhani, 2018).

Community Based Total Sanitation approach was adopted from the successful trial of Community Led Total (CTLS) which was successfully carried out in several drinking water and sanitation program locations in Indonesia, especially in an effort to increase public awareness to change the practice of open defecation into defecation in defecation that meets health requirements. Changing $\mathrm{BAB}$ behavior is a way to totally change the direction of sanitation through the five STBM pillars, with the first pillar of Open Defecation (BABS) being one of the efforts to break the chain of contamination from human feces to the environment, drinking water sources, food and others - others (Permenkes, 2014).

\subsection{Healthy Latrine Concept}

According to Proverawati and Rahmawati, (2017) a toilet is a room that can be used as a place of disposal or a place to collect human feces in certain locations according to health standards that have been determined with the following conditions: (1) The location of the toilet does not pollute water sources (distance collection of feces with a water source of at least 10 meters, (2) Comfortable to use and no smell, (3) Free from insects or rats, (4) Does not pollute the environment, (5) Easy maintenance and safe when used, (6) Has walls and roof, (7) Enough lighting and air circulation, (8) The floor must be clean and dry, (9) Equipped with cleaning tools, soap and water.

According to (Minister of Health, 2018) there are a number of conditions for processing large waste water (peses) in the community such as the following description:

Requirements for the environment. Requirements for the environment that must be fulfilled are: (1) Do not pollute the soil extraction; (2) Does not pollute groundwater; (3) Does not pollute water in the soil; (4) Does not pollute the air; (5) Insects / insects cannot be infested.

Requirements for Aesthetic. Requirements for Aesthetic that must be fulfilled are closed from an impolite view (disturbing the view).

Requirements for Economic. Requirements for Economic that must be met are: (1) building at an affordable cost, simple but standardized; (2) Can be used by everyone and easy maintenance Latrine Types.

Mubarak in Kurniawati (2017) argues that latrines according to their form and method of use can be classified into several types including: 
Pit Latrine. Pit Latrine is the simplest latrines that people use, but are less than perfect. Called cemplung latrine because only excavation and the top were given a floor so that the dirt immediately fell into the pit and directly to the ground.

Plengsengan Latrine. Plengsengan latrine is a place to remove dirt with oblique shaped channel that connects between squatting and disposal of dirt. When compared, Plengsengan latrine is better than cemplung latrine because the odor that comes out is less and safer for the wearer. And even better if the squat is closed, to prevent insects from entering.

Drill Latrine. Drill latrine is a type of toilet with a deeper pit of impurities than a pit latrine and plengsengan. Drill latrines are not suitable in rocky areas. The advantages are odorless, while the losses caused are pollution to the soil.

Water seal latrine is a closed type with a curved neck, this latrine does not cause odor and can prevent insects from entering because of their curved shape and storing water. This toilet is good for home use.

Overhung latrine. Latrines are made directly in rivers, swamps, ponds so that feces can fall directly into it and become fish food.

Latrine septic tank. This type of latrine uses one or more tanks that are walled in the ground to collect faeces with a boundary between one and the second tub. In the first tub the stool will rot and be destroyed by anaerobic germs so that sedimentation occurs and water will flow into the second tub.

\subsection{Clean and Healthy Behavior}

Clean and healthy living behavior in the family becomes part of the application / implementation to prove that all people on this earth have the right to be healthy, which needs to be respected and championed by all elements of society. Because of this on March 1, 1999 the President of the Republic of Indonesia declared that national development must be healthoriented, meaning that all fields of development must consider the impactarising from health.

According to Proverawati and Rahmawati (2017) all individuals can achieve their health if they are able to change behavior from unhealthy to healthy behavior and practice it in the family. The community will be able to apply clean and healthy life behavior if they have the thoughts, desires and capabilities of the policy makers as well as all related cross sectors and involve the participation of the community.

\section{Research Methods}

This type of research is an observational analytic study with a cross sectional approach that is the type of research conducted at the time of measurement or observation of data at one time at a time, conducted on independent variables and dependent variables (Sugiyono, 2017).cThis research was conducted in Bener Meriah Regency which consists of 10 districts with the following considerations: (1) Indiscriminate defecation (BABS) behavior of 36.7 percent, this is far from the minimum service standard target (SPM) of 100 percent the community does not defecate carelessly; (2) Achievement of clean and healthy living behavior is only 24.7 percent, (3) Achievement of total community-based sanitation is only 3.0 percent of the target of 100 percent; (4) The research location is easy to reach by researchers. 


\section{Discussion}

Defecation is influenced by several factors, including predisposing factors. Predisposing factors are factors that make it easier a behavior, adopted for later implemented by someone. Predisposing factors include: education, economic level, knowledge and attitude.

The effect of education on open defecation. Statistically shows the educational variables influence the behavior of defecation not arbitrarily with a value $(p=0.017)$. This situation explains that there is a tendency for the level of education of high household heads to have open defecation. The results of this study are in line with the research of Kawale, Thakur, Sharma, and Minz (2018) that the level of education greatly influences the behavior of open defecation. Respondents with primary education in rural areas of Bilaspur, Chhattisgarh, India were more likely to use latrines than those who did not complete primary school. The same effect was found at the level of education of the family head.

Education is one way for someone to get information and interpret it correctly as a cause of disease due to behavior. Indiscriminate defecation is more practiced in communities with low education as stated by Novitry and Agustin (2017). Communities who have completed formal higher education tend to use latrines compared to those who have no education or less education (Mukesh and Pandey, 2016).

New information that is constructive and requires change behavior becomes readily accepted by someone who is highly educated. This is the reason for education as one of the factors predisposing to healthy behavior such as the use of a toilet when defecating. More highly educated people in the Gunungpati District of Semarang, more who do not defecate carelessly (Oktanasari, Laksono, and Indriyanti, 2017).

In line with this, Saith Viswanathan, Lamba, Joshi, and Purty (2018) stated that education has a major influence on the behavior of open defecation. Research in India shows education in addition to being a major predictor of toilet use when defecating. India is one of the developing countries that has problems in using latrines, which is described by the lack of access to these facilities reaching 53 percent. The low use of latrines that indicates open defecation behavior is known to decrease in adult individuals who complete higher levels of education.

There is an influence of education on bowel behavior in this study because someone who has gained insight from a formal place to study will better understand a problem, especially related to health. Information obtained along with the duration taking education and increasing levels, becoming wider and more diverse.

Education provides literacy skills for everyone so they can quickly conclude the collection of information obtained. Information about bowel behavior that meets health requirements is very likely to have been known and reviewed by knowledge providers at every level of education. The insight gained from education greatly influences the perception and subsequent behavior of a person in implementing something.

Education trains the ability to assess a problem from various points of view so that there is no stagnation in solving a problem. Open defecation, apart from being known on educational trips, will have an impact on health and is very privacy. Someone who previously came from the environment with no regard for privacy when defecating, then becomes more 
concerned. Education in addition to expanding horizons causes a person's range of comfort to increase. Comfort when defecating that is accustomed to be obtained while studying, especially those who wander away from the family residence, will not feel comfortable defecating in the open.

Effect of economic level on defecation behavior. Statistically shows that the economic level variable influences the behavior of defecation not arbitrarily with the value $(p$ $=0.006$ ). This situation explains that there is a tendency of people with high economic levels to have defecation behavior not arbitrarily. The results of this study are in line with research by Odagiri et al., (2017) that the level of well-being is closely related to bowel behavior. People at a good welfare level are generally more obedient in using latrines compared to families with low welfare levels. Poor people mostly agree that open defecation behavior such as in rivers is acceptable and understandable.

The results of observations and secondary data found that in Bener Regency, the open defecation behavior due to not having a toilet was more common in families with low economic levels. Fitri and Putri (2016) state that the level of income of the head of the family is related to prioritizing the things that must be realized for the needs of the family. Low income level illustrates the primary needs are the main things that will be met, compared to the necessity of having a toilet. Open defecation due to the absence of latrines as found in one of the Kerinci Regency villages that the low income population did not have more latrines $(95.1 \%)$.

Indiscriminate defecation behavior in families with low economic levels in the study area due to various factors. Financial inability to build physical facilities is the main thing. The family will meet the needs that are considered more important than the building used for defecation. Another thing was found to be limited information and insight in looking at the importance of health problems. The impact of open defecation which in the end can cause both short-term and long-term illness with greater economic consequences is not important to consider.

In line with Yulda Fajar and Utama's research, (2017) that there are various factors that influence bowel behavior both internal and external. Income is the main influencing factor based on multivariate results $(\mathrm{OR}=6.464)$. Communities from groups with low income, even though they have received information about the health effects of defecation in rivers, gardens or bushes, find it difficult to change their behavior regarding the implementation of latrine construction. The realization of latrines that require more than the primary needs, makes the necessity of the availability of this facility not something that must be implemented immediately. The order of fulfilling needs is very dependent on income, so the priority of preventing disease is not in the first place.

Another factor that was obtained in the study area was that the continuity of the use of latrines could be related to the acculturation process so that changes in priorities occurred. The feeling of comfort has finally become a consideration for using latrines in people with high economics. Acculturation with a better life in realizing toilet physical facilities, persuading someone to be able to have a toilet for the family. Termination of the use of latrines in some cases is known to be due to damage to physical buildings or maintenance costs that are not owned by the family so that the use of buildings threatens safety. This in high economic circles, at a minimum occurs because of the ability to maintain buildings and renovate facilities. 
Effect of knowledge on defecation behavior. Statistically shows that the knowledge variable has no effect on defecation behavior, this situation explains that there is a tendency for the community to defecate carelessly in a community with high knowledge and low knowledge. The results of this study are in line with Samosir and Ramadhan (2019) that the knowledge variable is not related to the ownership of healthy latrines by the family. The people in Tanjung Pinang in this observation, even though they have high years of age, do not have latrines because most do not own land and are of the opinion that there is no evidence that this can affect health.

This result is not in line with Sukma and Nurjazuli (2018) that knowledge has a relationship with open defecation free (ODF) habits. People in Candisari Subdistrict, Semarang City who have high knowledge, tend to not defecate in any place. The tendency of open defecation is high in people with low knowledge.

The existence of research results in Bener Merian Regency which is not appropriate, that is knowledge as a predisposing factor for the occurrence of a behavior can be caused due to the support of other factors, namely confidence in the impact that will occur as the information already known. People who have a positive view that there will be health impacts due to open defecation will change their behavior. Other support for behavior change requires a strong will to dispose of the feeling of comforting open defecation. The assumption that defecation behavior is not in the toilet is an ethical thing, it becomes an obstacle that can inhibit the habit of not defecating openly. High knowledge but do not try to have good habits and assume no problem defecating in the open will be more comfortable, will not be able to change bad habits that have been done for a long time.

Behavior change is difficult especially when the practice has been part of a community's culture for a long time. Knowledge in the form of suggestions that invites people to think and evaluate the effects of defecation not in the toilet according to health standards, is an effective measure. The community is focused on being aware of the unhealthy aspects of the habit including something that has violated someone's integrity by exposing the most intimate things to an unknown person. The information provider must mingle with the community and understand the cultural aspects related to the behavior they want to change, if they have a target the community executes the information that has been provided (Selendy, 2019).

Research in the field also found that the lack of clean water was also one of the reasons people did not use latrines. The behavior of open defecation behavior, especially in rivers, is felt to be more fun because it makes it easier to clean yourself compared to having to carry water when doing it in a toilet. There are obstacles when using the latrine from the aspect of water is a barrier for some people to apply it even though they know that open defecation is a source of disease and pollution of water sources when doing so in the river. This illustrates that the aspect of high knowledge does not become a strong incentive for open defecation.

Effect of attitude on defecation behavior. Statistically shows the attitude variable influences open defecation behavior with a value $(p=0,000)$, this situation explains that there is a tendency for positive community attitudes to have open defecation behavior. The results of this study are in line with the research of Sara and Graham (2014) who found that families with a supportive attitude tended to utilize the use of latrines when defecating. Utilization of latrines is encouraged by the belief that the actions taken have a good impact on health. 
In line with research by Paramita and Sulistyorini (2015) that attitude is one of the internal factors that influence the use of latrines. Research in Gempolklutuk Village, Tarik District, Sidoarjo, East Java Province shows that there are still 35.1 percent of families who have not used latrines properly and attitudes that are classified as sufficient are 38.6 percent. The attitude of the head of the family illustrates the family who have not fully utilized the toilet when defecating and this factor is a determinant of the low utilization of the toilet.

Tessema's study (2017) published similar results that attitudes greatly influence the use of latrines. Research in the Diretiyara District, Eastern Ethiopia, found that latrine ownership rates reached 89 percent and that has improved its latrine with a community-led total sanitation and hygiene (CLTSH) program of 78 percent. Data collection showed that 11 percent of respondents admitted that they still had open defecation because they supported the action more than defecating in a smelly, uncomfortable toilet. Unpleasant latrines have caused 58 percent of respondents to inconsistently use the facility to defecate.

Defecation behavior is influenced by the attitude found in this study because someone who already has a variety of insights, requires positive impetus for the action he will do. The good information obtained will not be realized as suggested if the view of the action is not believed to have an impact as has been informed. Attitude greatly influences decision making in acting after knowledge. A positive attitude in the form of similarity in the view that bowel behavior is not in place other than unhealthy, being unethical because the activity is not privacy, is something that can affect bowel behavior after being informed about the effects of these actions. The similarity in mental outlook to change bowel behavior, will be a powerful incentive to apply it to the people closest to it so that there is commensurate understanding in taking action.

\section{Conclusions}

Based on the results of research and discussion, it can be concluded that: The education of the head of the family has an influence on the behavior of open defecation. The economic level of the head of the family influences the behavior of open defecation. The attitude of the head of the family has an influence on the behavior of open defecation

\section{References}

Achmadi, U.F. (2012). Manajemen penyakit berbasis wilayah; paradikma kesehatan lingkungan. Jakarta: Buku Kompas

Alemu, F., Kumie, A., Medhin, G., \& Gasana, J. (2018). The role of psychological factors in predicting latrine ownership and consistent latrine use in rural Ethiopia: a cross sectional study. BMC Public Health, 18, 229 https://doi.org/10.1186/s12889-0185143-0

Ali, Z. (2010). Dasar-dasar pendidikan kesehatan masyarakat dan promosi kesehatan. Jakarta: CV.Trans Info Media.

Anwar, S. (2017). Sosialisasi pentingnya tidak membuang air besar di sungai (Stop BABS) di Desa Gampang Kecamatan Prambon. Jurnal Abadimas Adi Buana, 1(1), 43-48.

Apriyanti, L., Widjanarko, B., \& Laksono, B. (2019) Faktor-faktor yang mempengaruhi pemanfaatan jamban keluarga di Kecamatan Jatibarang Kabupaten Brebes. Jurnal Promosi Kesehatan Indonesia, 14(1), 1-14. 